\title{
A Literature Review of Indonesian Life Concept Linuwih Based on the Teachings of Adiluhung Raden Mas Panji Sosrokartono
}

\author{
Bakhrudin All Habsy \\ Department of Guidance and Caounseling \\ University of Darul Ulum Jombang, Indonesia \\ bakhrudin_bk@yahoo.com \\ Nur Hidayah \\ Department of Guidance and Caounseling \\ State University of Malang, Indonesia \\ nurhidayahum@yahoo.com
}

\author{
Blasius Boli Lasan \\ Department of Guidance and Caounseling \\ State University of Malang, Indonesia \\ blasiusbolilasan@yahoo.co.id \\ Muslihati \\ Department of Guidance and Caounseling \\ State University of Malang, Indonesia \\ muslihatiyusuf@gmail.com
}

\begin{abstract}
Abstrack: The linuwih counseling study is based on the importance of the counselor to understand the noble values and meaningfulness of the counselee's life. Counselor's understanding of the counselee's life is passed on as counselor's expertise to creater the potential resources of the counselee as a manifestation of a more meaningful quality of life through sophisticated efforts based on cultural understanding of the counselee. The principles of Raden Mas Panji Sosrokartono that are formulated in pockets of science, science, psychology and behavior, the science of chess murti and revealed in various pearls sabdanya produce profound philosophy and presenting a new view of the dynamics of meaningfulness of the human soul to become a figure Man linuwih. Various wewarahan, moral cultivation of virtuous life and the direction of life Raden Mas Panji Sosrokartono held and used as a guide of Indonesian people especially in Java. The focus of this research is the application of the superior teachings of Raden Mas Panji Sosorkartono as the cultural counseling framework of Indonesian culture.
\end{abstract}

Keywords: counseling linuwih, teachings adiluhung raden mas panji sosrokarton

\section{INTRODUCTION}

The development of contemporary counseling theories are more developed and developed in Western countries, mostly developed by counseling figures from the Jews, this makes Western counseling philosophy used by counseling users in Indonesia, ranging from counseling techniques to the nature of human results imitating and practicing western counseling theories and approaches. Western country counseling applied in Indonesia put forward on positivism that is observed and measured related to the symptoms of behavior, in this dominance empirical counseling, inductively growing rapidly with experiment and statistic, so from side of ontology, axiology and epistemology make discourse Individual culture-induced counseling that relies on intuition on qualitative analysis is not much developed.

The Western state of counseling tends to serve as a key reference in the delivery of counseling services in Indonesia, such as Rational Emotive, Psychoanalysis, Behavioral (mechanistic or environmental response system) Rogerian (rational human being, trustworthy and capable of doing better, has a desire to be more meaningful), and Gestalt (man has the ability to accept personal responsibility and live as a whole person) (Gibson \& Mitchell, 2011). Among the schools of Western counseling there is not a single western counseling view that is able to accommodate the philosophical views of Indonesian humanity as a whole, personal and western and eastern taste is different, the more open and private personal. West is more closed in every way. The Western school of counseling has many shortcomings regarding sociocultural understanding (Corey, 1995).

The western school of counseling which is considered and referenced in counseling around the world is good but western counseling schools are not like the scriptures of a Religion that must be run throughout the contemporary times. According to Khun theory that evolved, the theory always experienced a development in the direction of the development of time in which the discovery of new theory more acceptable to a scientific community (Hanurawan, 2012). According to the view of Thomas S. Kuhn and Karl Popper shift old theory to the theory of the new theory are the implications or consequences of the automatic nature of empirical evidence and the most successful rationally deny or abort the old theory of truth (Hanurawan, 2012). In line with the development padardigma theory of counseling, a paradigm shift of thinking that thought regarding indigenous counseling Indonesian specialties began to grow, in this case, the counselor dignity should not be working with a borrowed philosophy that has been built by others (Shertzer \& Stones, in Mappiare, 2013) as done by the initiator and guardian of profession Guidance and Counseling Indonesia, Prayitno, wrote Counseling PANCAWASKITA by integrating five factors that affect the individual, namely: (1) Pancasila; (2) Liharid; (3) Pancadaya; (4) Masidu; and (5) Likuladu (Prayitno, 1998) and Andi Mappiare AT, who concocted National Culture-Based Counseling models: KIPAS (Intensive Counseling Against Adaptive Progressive Structure Model KIPAS formulation comes as an effort to realize the noble dignity profile counselor Indonesia, namely: (1) the profile dignity inherent in the philosophy; (2) profiles dignity in personal counselor; (3) profiles of dignity on the basis of national culture; (4) the profile of dignity in the design model; and (5) the profile of dignity in the tangible results of counseling. 
According to Model KIPAS dignity counselor and once counselees Indonesia already embodied in the motto 'unity in diversity as a valuable raw and powerful noble, Eagle as a symbol of the State, Pancasila as the state, and Sangsaka Red and White (Mappiare, 2013).

The users of counseling services in Indonesia are expected not only to learn and practice the theories and approaches expressed by Western countries, but also able to formulate new paradigms with empirical and rational evidence of the distinctive Indonesian cultural counseling with basic on Indonesian cultural peculiarities. Indonesian counselors need to develop their own self-awareness about the nature of Indonesian human beings by not borrowing "clothes" of western counseling. Counselors are required to have cultural sensitivity and the ability to break away from cultural biases. According to Habsy (2017) the history of counseling emergence in Indonesia has existed since 1000 years ago when Ki Lurah Semar gave Counseling to the pandawa who were experiencing the inner conflict, the form of primitive counselors in the past is practiiced by chiefs, healers, shamans, which is considered to be able to calm the heart, or provide predictions in the future.

According to Corey (in Habsy, 2017) complex culture has its own philosophical and thought-based foundations in many respects, which in this case is about a counseling approach. According to Kim \& Hwang (2008) to apply the approach of psychology or counseling of the West without a sharing with the local culture is a necessity that should get a thorough evaluation. Further Watson (2011) states that the foundations, procedures and techniques of counseling developed in western culture are equal position among counselors and counselors. Indonesian culture as an Eastern culture tends to view counselor as someone who has a parent position. Parents themselves have an honorable position in the life and life of a child. This is different from the tendency in western culture. The basis of procedures and the counseling techniques developed in western culture is the equality of positions between counselors and counselors, cultural constraints can lead to problems for counseling practice in Indonesia. Cultural identity is a personal matter (Zaretsky, 1995: 246). According to Casson (in Ridjal, 2000) view culture as an idealized cognitive system that exists in individual thinking. It can be concluded that the cultural identity has been established in the cognitive structure of individual western and eastern cultures, the cognitive structure is the symbolic mind that guides their actions which are the legitimacy of the identity of their thoughts and actions. Certainly the inclusion of western schools of counseling paradigm in eastern culture as a threat to their established cognitive structure.

According to Pedersen (1991) in the field of counseling and psychology, the cross-cultural approach is seen as the fourth force after a psychodynamic, behavioristic and humanistic approach. Cross-cultural views are characterized by a holistic approach to help and healing, focusing on groups and individuals. The practice of counseling in
Indonesia, should apply the concept and practice of counseling by adjusting the cultural values of the Indonesian nation. According to Collins \& Arthur (2007) states that counselors should be aware of their own cultural heritage, this is in line with the opinion of Zenner etc. (2016) states that as a counselor should be able to divert their attention to counseling by incorporating issues cross-cultural issues. According to Collins \& Arthur (2010) states: (1) counselors are encouraged to become aware of their own cultural identity as well as cross-cultural dynamics; and (2) the counselor should adapt cultural characteristics of the counselee and pay special attention to cultural characteristics of Counselee.

Indonesia is a large country consisting of various religions, tribes, cultures, and customary law communities, even listed as the country with the greatest amount of local wisdom in the world, it would be feasible if we have the goal to make the knot more qualified counseling than the Already developed by the West. The more important reason is, the sense of nature in Indonesia is different from the emotion or feeling in America, the ancestors of Indonesia have known the natural taste that colored various wisdom in looking at the world, one of them is hamemayu hayuning bawono concept (Endraswara, 2013). Sophisticated and scientific reasoning is needed in an effort to realize the adjustment of counseling practice in Indonesia that adapts to the unique Indonesian cultural values. According to Goodwin \& Giles (2003) that Indonesia has a diverse culture, one of the Indonesian nationals who deserve to be exemplified in their lives and can be used as a reference to become a typical Indonesian culture counseling is the precepts of Raden Mas Panji Sosrokartono.

Raden Mas Panji Sosrokartono is the brother of national hero of Raden Ajeng Kartini, since childhood has the privilege, he is intelligent and has the ability to read the future, he is a polygot who controls 24 foreign languages, and 10 tribal languages in the land of Nusantara (Syuropati, 2014). Raden Mas Panji Sosrokartono devotes all his energy and his mind to the benefit of the people, and becomes a fellow human being who suffers both physical and spiritual pain (Paroesno, 1954). Raden Mas Panji Sosrokartono is very passionate towards his neighbor, the benefactor, the unselfish benefactor, does not seek reward, because the principle of his life is: leladi sesameng dumadi, memayu hayuning sesami (Suxmantojo, 1978). This is in accordance with the characteristics of effective counselors according to Corey (2012: 17) that effective counselor is a profitable counselor for counselors and have a positive view of personal characteristics and abilities. Furthermore according to Mappiare (2010) counselor is an altruistic person who with the willingness to sacrifice (time, energy, and perhaps material) for the benefit of happiness or pleasure of others.

The noble teachings (adiluhung) of Raden Mas Panji Sosrokartono were born after Raden Mas Panji Sosrokartono returned to Indonesia in 1925 after being from Europe for 26 years. In the year 1930 until the end of his life Raden Mas Panji Sosrokartono deepend 
the field of kebatinan communicated and developed in paguyupan monosoeko "Daroesalam". The life course of Raden Mas Panji Sosrokartono from humans who live in an agrarian Javanese tradition became a learned man and lived in the modern world for 26 years in Europe, then returned to Java to explore the fascinating world of death for study (Paroesno, 1954). He was a nobleman, a scholar, an unsung hero, a philosopher, a rich man without a throne, a scholarly yogi, Mandor Klungsu, Jaka Pring, pockets and personal-private descendants or berkantong bolong and gurune pribadi muride pribadi (Paroesno, 1954).

According Prayatno (2013) Venerable teachings Raden Mas Panji Sosrokartono is a product of reflection submitted in the form of wejangan written in a letter interpreted as noble pitutur. Furthermore, Partosatmoko (1966) explains that moral guidance, benevolent cultivation and the direction of life of Raden Mas Panji Sosrokartono not only carve the words of pearls, but more than that, he always run what he wrote in the form of acts of greed concrete behavior. The science and behavior of Raden Mas Panji Sosrokartono is explicitly directed to show the truth and meaning of exemplary that is worthy of being followed by all human beings. This is in line with the opinion of Corey (2012) counselor is a person who is able to provide exemplary for the counselee who served, and put the interests of others rather than personal interests (Gladding, 2012).

Raden Mas Panji Sosrokartono dub himself as the Mandor Kelungsu and Jaka Pring, the meaning behind the title Mandor Kelungsu is the leader who runs the dharma devotion as a helper for anyone who needs, selflessly done lovingly as a form of charity because virtue is a form of alms. From a piece of fibers Raden Mas Panji Sosrokartono written: mandor Kelungsu dermi ngelampahi kemawon, namung mados barang ingkang sae, sedoyo kulo sumanggakaken dateng Gusti, Kula saged nindhakaken ibadat inggih puniko kewajiban bakti lan suwita kula dhateng sesami (Sosrokartono, in Aksan, 1995) Whose meaning Mandor Kelungsu is only looking for something good, I leave everything to God, I can only practice worship that is obligation of worship and serve to others. This is in line with Brammer's opinion that the person of the counselor is Ability so serve as the model and influencer whose meaning that the counselor has the ability to serve the counselee as an example and leader or influential person. The ability of a counselor as a leader or foreman is indispensable in the counseling process. While the meaning of Jaka Pring is a young and honest man who is beneficial to everyone. This is in line with the ethical code of the counselor profession set forth in the text of the ethical code of Indonesian Counselor profession that the Counselor is obliged to provide services to anyone especially in an emergency or many people want it (ABKIN, 2009).

Raden Mas Panji Sosrokartono in helping humanity manifested in leladi maring sesami principles whose meaning helping others in need is done with strings attached suwung pamrih whose meaning selfless as a form of worship to love and mengadi to God and fellow human beings. As a servant he has a life motto is: soegih tanpo bondo, Digdoyo tanpo adji, Ngaloeroeg tanpo bolo, Menang tapo ngasoraken, Trimah mawi pasrah, Soewoeng pamrih tebih ajrih, Langgeng tan ono susah tan ono seneng, Anteng manteng soegeng djeneng (Askan, 1998), which means rich without wealth, without talisman Way, Attacking without an army, Win without demeaning, Accepting the resignation, no strings attached away from the fear, the Eternal hath no sorrow, no love, Quiet centered, unhappy reign. His life motto as if to imply the spark of individual life as members of society, as expressed $\mathrm{Ki}$ Hadjar Dewantara (1967) that the art song most associated with the character of Java psychotherapy or psychological picture. From these explanations can be interpreted to mean that life motto Raden Mas Panji Sosrokartono is papeling or reminder to be a human figure linuwih (superior) is people who care about the fate of others, people who seek to help others, both power and mind, which is described in the pockmarked sciences, Science sunji, empty pockets and psychology and behavior.

According to Ali (1966) pockmarked sciences is the life teachings of Raden Mas Panji Sosrokartono in the early era of 1933 whose meaning: nulung pepadane ora nganggo mikir wayah, waduk, kantong yen ana isi lumuntur marang sesami contents, meaning to help fellow humans do not need to think about time stomach, bags if any contents donated to others. Pockets of knowledge have two fundamental principles: (1) selfless emptying; and (2) helping fellow human beings. It can be interpreted that pockmarked pockets are manifestations of help to humans without asking for reward as a form of devotion to God. This is in line with the responsibility of counselor professionals who must serve all counselors who need help by improving their welfare and protecting them from harm (Hepner, Wampold, \& Kivlinghan, in Habsy, 2017). Furthermore, empty pocktery is a human love for God, and Science Sunji is a proclamation of love to God by risking body and soul to help fellow human beings (Ali, 1966). This is in line with the competence of Indonesian Counselor personality that is: (1) displays personality that is faithful and pious to God Almighty, Consistent in carrying out religious life and tolerant to other religions; and (2) morality and noble character (ABKIN, 2009)

If Back in 1964 proposed the concept of human personality structure consisting of situation, automatic thought, cognitive, emotions, behaviors and physiological reactions (Habsy, 2017), Raden Mas Panji Sosrokartono in the 1930 s described the concept of personality dynamics with the name Chess Science murti is four manifestations consisting of thoughts, feelings, words, and deeds (Aksan, 1995). Science of catur murti is the process of control thinking to the desire or the will (feeling) that causes words and deeds. The science of catur murti connects intangible feelings of desire or desire with the mind to be able to master feelings (nglaras batos saha raos) which will bring goodness to deeds and words (Aksan 1988). 
Cognitive Behavior Therapy Aaron Beck (1964), a psychologist known as The Father of Cognitive Behavior states the approach of cognitive behavior is an approach that aims to change the cognitive or perception that is a the tendency of individual minds to certain situations or events that affect emotions, behaviors, and indirectly affect physiological reactions (Beck, in Habsy, 2017).

Given the importance of the overall presentation of the teachings of the noble Raden Mas Panji Sosrokartono, then conducted an in-depth scientific assessment in the form of explorations of texts of the teachings of the good, Raden Mas Panji Sosrokartono which allegedly can be applied in counseling. The authors suspect that there is a point of similarity or relevance between the study of the teachings of the noble Raden Mas Panji Sosrokartono leads to the flow of cognitive behavior approach as the dominant theoretical framework (and road map) in this study, as shown in the previous explanation, ie cognitive or individual perception of Herself has an effect on emotional and behavioral changes. The author's point of view as a very positive endeavor if counseling studies based on the teachings of Raden Mas Panjan Sosrokartono's worth as indigenous counseling can be applied and studied for counseling service users in particular counseling practices based on Javanese culture believed to be adaptable, integrated, absorbed, and / Or transferred into Indonesian counseling style.

The study of the noble teachings of Raden Mas Panji Sosrokartono where there is a point of equality or relevance to counseling is prepared using a counseling framework by Gerald Corey. According to Corey (2015) a complex culture has its own philosophical and thought-based foundations in many respects, which in this case is about a counseling approach. The framework created by Gerald Corey in compiling a systematic theory of counseling and psychotherapy, includes: (1) basic philosophy, which gives the idea of the nature of man in a theory; (2) the main concepts, including the description of a theory about the structure of human personality; (3) the goal of therapy, which provides an overview of the changing conditions and description of a positive effect of the counseling or psychotherapy approach; (4) therapeutic relationships, which describe the counselor's tasks and experiences the counselee gained during the counseling process; and (5) therapeutic techniques, which include the distinctive techniques of a psychological theory used to assist counselees during the counseling process.

\section{METHODS}

This study uses qualitative methods that intend to understand the phenomenon of what is experienced by research subjects such as behavior, perception, motivation, action, etc., holistically, and by way of description in the form of words and language, in a special context that is natural and by utilizing various natural methods. This type of research is a hermeneutical approach serves as a tool to trace or reveal the meaning in the text, discourse, and interpret the problems as in the text of the teachings of the noble Raden Mas Panji Sosrokartono. Subsequently, concepts where the equation or relevance points are established using Gerald Corey's systematics include: Key concepts, therapeutic processes, counselor functions and roles, counselor experience in therapy, and therapeutic techniques and procedures. Therefore, Ricouer hermeneutical approach design is appropriate for this study because it presents descriptive, interpretative, and explanative explanations and descriptions.

Data collection is obtained from the study of the teachings of the noble teachings Raden Mas Panji Sosrokartono with a number of books, namely: (1) Ilmu dan Laku, RMP Sosrokartono, by Aksan (1995); (2) Gema Suara, RMP Sosrokartono by Aksan (1995); (3) Ilmu dan Laku, RMP Sosrokartono, Surabaya Citra Jaya Mukti by Aksan (1988); (4) Kumpulan Seratserat, RMP Sosrokartono, by Suxmantojo (1971); (5) Kumpulan serat-serat Drs. RMP Sosrokartono, by Suxmantojo (1931); (6) Ilmu Kantong Bolong Ilmu Kantong Kosong Ilmu Sunji, RMP Sosrokartono, by R. Mohammad Ali (1966); and (7) Ajaran-ajaran Adiluhung Raden Mas Panji Sosrokartono, by Mohammad A. Syuropati (2015).

\section{RESULTS AND DISCUSSION}

The powerful teachings of Raden Mas Panji Sosrokartono revealed in various pearls of his sabd and his collection of fibers give piwulang about basic human motives manifested in the deeds of leladi sesammeng dumadi, memayu hayuning sesami to go to the Alif the human figure linuwih / superior (Suxmantojo, 1977). From a piece of texts of the teachings of the noble Raden Mas Panji Sosrokartono expressed as follows: masang Alif puniko inggih kedah mawi sarana lampah, boten kanging kok lajeng dipun canthelaken kemawon, lajeng dipun tilar kados mepe rasukan, which means to install Alif it must with the suggestion of appreciation (lampah laku), should not just be put on hold (Suxmantojo, 1971). Alif is a description of the kesunyatan (reality) obtained through Lampah Laku Catur Murti which is a blend and unity of thoughts, feelings, words and deeds (Syuropati, 2015).

Raden Mas Panji Sosrokartono (in Suxmantojo, 1971) says: wajib tiyang gesang sinau anglaras panginten saha raos, meaning that the living person must learn to harmonize between mind and feeling. It can be interpreted that thoughts and feelings are so necessary to be corrected so as not to be easily affected by anger, hatred, envy, jealousy, and the like. This is in line with the task of a cognitive behavioral counselor who helps the individual, understanding how he can form a cognitive distortion by adjusting to his emotions and thoughts (Somers, Habsy, 2017).

Kesunyatan Alif is a manifestation of ingsun (self) to manifest unwarranted human beings giving up the character traits (menungso tanpo ciri) that give strength, enlightenment and spirit of life (Aksan 1995). In a person there is the teacher of the self (the true self) and the student himself (identity), I am my teacher, and I am his disciple I (Aksan, 1995). 
According to Suseno (2001) ingsun (personal) in Javanese culture understood as self (diri) which is accumulation of human's inner and outer dimension, the visible self is the total number of body parts ie mind, sensation, lust and whisper of heart. This is similar to the opinion of CG Jung seoarang swisher of the Swiss in his work entitled Modern man in search of a soul which states that humans are created with the meeting Naturprinzip and Geistprinzip. My Jung's paradigm has its own realm of conscious and consciously conscious nature, which is taken into consideration to regulate the human soul, the encounter between the conscious and the conscious conscious realm to find intuition (Jung, 1935).

Raden Mas Panji Sosrokartono divides the categories of Alif into four color categories which lead to his function for the achievement of human level which ngawulo dateng kawulaning gusti lan memayu hayuning bawono (man who serve to God and improve the beauty of life) that is: (1) white is balance, and peace; (2) black is self-control, stability, neutrality, quiet power; (3) light blue is creativity, spiritual, heavenly, truth, healing and physical healing power; and (4) red is something life force, power sustainability, to protect attacks that will forge the body, facilitate blood circulation and courage (Aksan, 1995). This is in line with the opinion of Jung (2001) which states that every human being can reach the level of collective conscious, for example Yezus christ. Jezus is a historical human, collective conscious of Yezus has risen to a collective consciousness called Christ. Jung enters the field of trust and intuition in the human psyche that is not inferior to the power of the human mind.

Based on the above data exposure can be interpreted that the teachings of noble Raden Mas Panji Sosrokartono presenting a new view of the dynamics of meaningfulness of the human soul to be a human figure ngawulo dateng kawulaning gusti lan memayu hayuning sesami. Alif's allegiance is a manifestation of the ingsun in the context of Javanese culture understood as the self which consists of the teacher of the self (the true self) and the self-disciple (self) which is the accumulation of the inner human dimension by performing the four functions of the self self) are: (1) white; (2) black; (3) light blue; and (4) red. To realize kesunyatan Alif obtained through the Lampah Laku Catur Murti which is a blend and unity of cognitive, feelings, words and deeds, which are united in a stillness / soul / spirit and invisible by the senses by holding "inner conection" with God or In Javanese culture it is understood as the whisper of the heart that produces inner vision, inner voice, inner streght, inner power so that man can attain a true truth that can incite the negative will / feel.

The basic human philosophy based on the great teachings of Raden Mas Panji Sosrokartono in this case is commonly referred to as Alif's travel cart, which is the imagination of a train with four horses consisting of thoughts, feelings, words and deeds by walking through the "lampah laku catur murti ". Ingsun or self as a representative of alibi kasunyatan who served as coachman (the driver) in controlling the horse to achieve a silence to get a whisper of heart, the train alif in visualize in Figure 1 as follows:

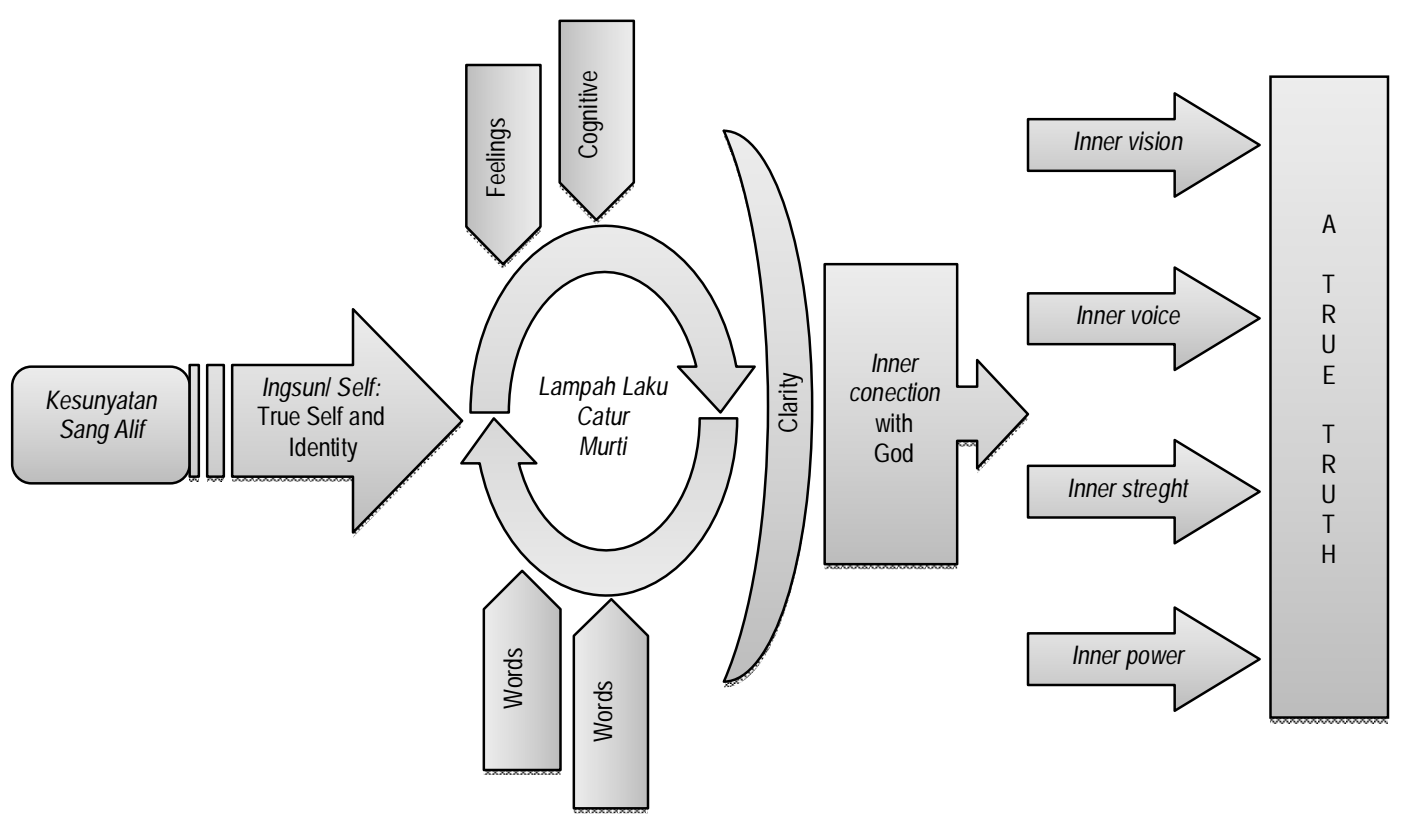

Figure 1

Train The Alif Based on Teachings Adiluhung Raden Mas Panji Sosrokartono

Efforts to disseminate and systematize each of the teachings written in the fibers of Raden Mas Panji Sosrokartono, to build a unified and integral science that gave birth to the concept of Javanese human personality structure based on the noble values of Raden Mas Panji Sosrokartono. This is alleged from cross-cultural psychological thinking by Trandis (in Jatman, 1997) stating that there is no positivistic 
psychology that is applicable objectively, universally everywhere, so the concepts that apply to one group of nations may not necessarily apply to other nations, such as rasa In Java is not the same as emotion or feeling in America.

Discussion about the structure of human personality contained in the Science of Catur Murti is a unity of four physiology that is thoughts, feelings, words of action (Aksan, 1995). The process of human desire or will causes people to think and act and say. The mind that hates, encourages us to say hatefully, the mind that hates the birth of hateful acts (Aksan, 1995). According to Raden Mas Panji Sosrokartono (in Aksan, 1995) right thinking can bring benefits to us and bring the truth to words, deeds and feelings. Righteous thoughts contain love, compassion (welas asih), sympathy, and calm. The science of catur murti enforces an intangible feeling of desire or desire with the mind to be able to master feelings (nglaras batos saha raos). Can be interpreted that the mind affects the way individuals interpret the events in life that make each individual has a meaning and reaction to deeds and words.

This is similar to the view of Cognitive Behavior Therapy Aaron Beck (1964), a psychologist known as The Father of Cognitive Behavior Therapy defines Cognitive Counseling Behavior is an approach that aims to change the cognitive or counselee perception of himself in order to make changes emotions, Behavior and physiological reactions of counselees (NACBT in Habsy, 2017). According to Raden Mas Panji Sosrokartono (in Aksan, 1995) Catur Murti, if studied, lived, deepened and practiced make the hamemayu hayuning urip, who later became the leader of the character bares (honest), wani (brave), and mantep (sure) (Suxmantojo, 1931).

From the above explanation can be concluded the teachings of the noble Raden Mas Panji Sosrokartono has been presenting a new view of the personality structure consisting of thoughts, feelings, words of action. Desire or will causes the thought process to give rise to certain feelings and actions. The science of chess murti connotes intangible feelings of desire or desire with the mind to be able to master the feelings (nglaras batos saha raos), human beings can change the way of thinking to produce behaviors that, who later become leaders of character bares (honest), wani (courageous), And mantep (sure). Visually, the structure of the human personality based on Semar's noble values, visualized in Figure 2 below:

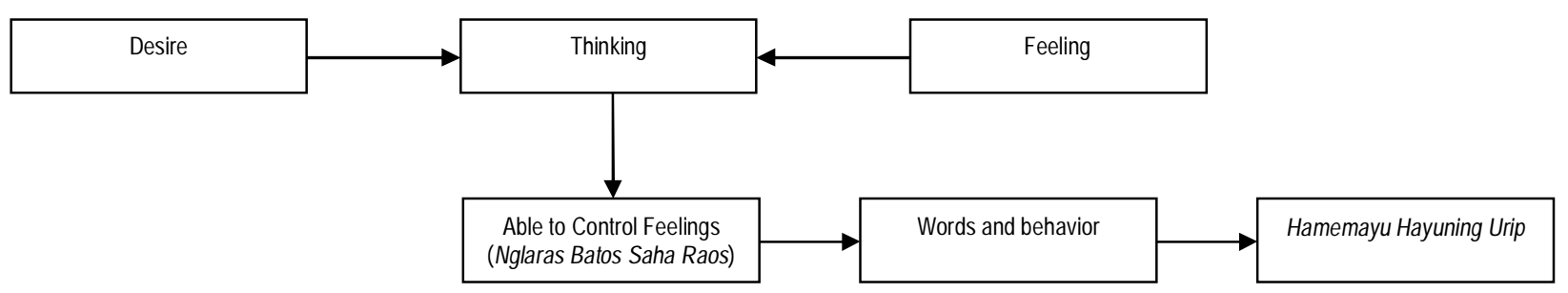

Figure 2

Structure of Human Personality Based on Teachings Adiluhung Raden Mas Panji Sosrokartono

Actualization and contextual teachings Raden Mas Panji Sosrokartono valuable if implemented by the Indonesian human race then, human nature individualistic, matarialistis and secularity can be minimized. From a piece of text valuable teachings Raden Mas Panji Sosrokartono between narrative found from the speech that is ikhlas marang apa sing wis kelakon, Trimah marang apa kang sakiki dilakoni, Pasrah marang kang bakal ana (Hisar, 1998; 21). Based on the exposure data can be interpreted to mean that the valuable teachings of Raden Mas Panji Sosrokartono teaches that to achieve serenity in life should have the ability to develop an attitude of living to what happens in the human past to mengikhlaskan, without remorse as a lesson for the future. Against whatever happens in the present moment man must accept it wholeheartedly, no need to be disappointed. As for what will happen in the future man must surrender or surrender, no need to be discouraged. Opinion Raden Mas Panji Sosrokartono are correlation with the theory of choice (choice theory) which is the road to happiness man according to Glasser stated that the theory of choice is that even though the past may have contributed to the current problems, and in spite of the events of the past, for the effective functioning of individuals Need to live and plan in the present (Galsser, in Jones, 2011).

According Hisar (1995) states the purpose of the valuable teachings of Raden Mas Panji Sosrokartono is papeling / reminder to be a human figure linuwih / superior to the man who is superior and indifferent to the fate of others, by trying to help others. The set of teachings valuable Raden Mas Panji Sosrokartono that terumus in the motto of his life is: soegih tanpo bondo, digdoyo tanpo adji, ngaloeroeg tanpo bolo, menang tapo ngasoraken, trimah mawi pasrah, soewoeng pamrih tebih ajrih, langgeng tan ono susah tan ono seneng, anteng manteng soegeng djeneng (Askan, 1998), which means: rich without possessions, best without talisman, attacking without an army, win without demeaning, accept with resignation, no strings attached away from the fear, the eternal hath no sorrow, no love, quiet converge, happy throne. Interest sublime teachings of Raden Mas Panji murti Sosrokartono in science teaching chess to manage thoughts on the meaning of events in life that make each individual has a meaning and a reaction to the actions and words. According Aksan (1995) by managing a well thought would contain the attitude of love (love), compassion (welas asih), sympathy and aum santih (calm and balanced), and 
protected from contamination such as hatred, greed, Envy, slander, and stupidity.

From the above explanation can be concluded the teachings of the noble Raden Mas Panji Sosrokartono has given birth to individual understanding and groups of Javanese community about therapeutic goals based on the teachings of noble Raden Mas Panji Sosrokartono is to form a person who has a human counselee linuwih or superior, Live life, and humans who woo hayuning urip by organizing thoughts that will bring changes to feelings, actions and words with the attitude of cinta kasih (compassion), welas asih (mercy), sympathy and aum santih (calm and balanced).

Raden Mas Panji Sosrokartono not just scraping mere buzzword, but more than that, he is always doing what he wrote and say with concrete actions (Partosatmoko, 1972). From a piece of text valuable teachings Raden Mas Panji Sosrokartono wise pearls express the relationship between teachers and students as follows: murid gurune pribadi, guru muride pribadi, pamulange sengsarane sesami, ganjarane, ayu lan arume sesami (Suxmantojo, 1971). This means the disciple of his or her own teacher, the teacher of his or her own self, the place of learning of the suffering of the neighbor, the reward of goodness and the fragrance of others. According Aksan (1995) proposition Pupil Teacher personal and private students can give meaning that there is a teacher in an individual self (the true self) and student self (identity), I was a teacher I am, and I was a student I was. Teachers can be interpreted denotative word as mulang kaweruh (giving directions), guiding students to understand the dimensions of the inner and outer himself that his true self and identity to achieve catur murti, it is commonly referred to as the agility of creativity, feeling and intention. This is in line with the opinion of Corey (2005) states that the counselor in handling problems needed a healthy selfunderstanding. Further Mappiare (2011) states the counselor should be responsive to changes in attitudes, perceptions, and expectations of clients against it.

The concept of the relationship between the individual disciple, the personal students master embodied in the letters of Raden Mas Panji Sosrokartono (in Suxmantojo 1971) is pamulange, sengsarane semsami and ganjarane, ayu lan arume sesami. The meaning of pamulange, sengsarane semsami is to understand the suffering or misery of others, one can draw wisdom and lesson from it. By looking at the reality of life dominated by sengsarae sesami it is necessary to: sinau ngaraosken lan nyumerapi tunggalipun manungsa, tunggalipun rasa, tunggalipun asal lan maksudipun agesang (Suxmantojo, 1971) whose meaning to understand the meaning of life and life it is necessary to learn to feel and know That man is one, sense is one, comes from the same place, and learns to understand the meaning and purpose of life. It can be interpreted that pamulange, sengsarane semsami is a form of empathy to feel and understand the world of others appropriately, this is commonly called expertise of empathy. According to Rogers (in Bozart, 1997) a helper must have the ability to understand the world of the client and feel it, or echo the emotions of the experience, as if it were a relief experience without any element of permissiveness.

The concept of ganjarane ayu lan arume sesami, which means to give understanding that someone who has made the suffering of fellow as a place and learning materials, then he will get the reward and the reward is the presence of good for him. It can be interpreted that ganjarane ayu lan arume sesami as the ability to help others with sincerity, this is commonly called expertise of help. This is in line with the opinion of Corey (2013) that the helper figure to provide sincere and harmonious to provide service to the counselee. Further Kolden, Klein, Wang \& Austin (2011) a sincere helper can help the counselee to be more aligned, making it easier for them to acknowledge their feelings and express themselves.

Raden Mas Panji Sosrokartono naming himself as the Mandor Kelungsu and Jaka Pring (Suxmantojo, 1971). The meaning of Mandor Kelungsu is the leader whose position as giver and surrender all his ability to help all those who need selflessly as a sadaqah (Aksan, 1995). It can be interpreted that the mandor kelungsu foreman is a figure of a virtuous leader whose duties as a helper and benefactor to others without demanding a reward, this is commonly called the virtuous Leadership leader. This senend with the opinion of Bitter (2013) character of virtue is the character of a helper. Furthermore Sullivan, et al (2007) states that a helper is trained to develop a wise and effective self-habits, as a way of looking at a world of noble deeds and ideals. The ability of the counselor as a leader in this discussion is mandor kelungsu required in the process of counseling.

Jaka Pring is a young, honest man who benefits everyone. In addition to Jaka Pring made a name by Raden Mas Panji Sosrokartono also once wrote as tembang as follows: "Pring padha pring, Weruh padha weruh, Eling tanpo nyanding" (Suxmantojo, 1971) which means "Bamboo equally bamboo, Just remember, Remember without approaching". It can be interpreted that Pring padha pring bamboo remains bamboo despite its many kinds, whatever kind of nation, religion, race, color, language and tribe we still respect / understand fellow human (Pring padha pring). It can be concluded that Pring padha pring is a figure of a helper who can adjust cultural differences, in this discussion commonly called the cultural consciousness. This is in line with the opinion of Aten (2010) which states that counselors are required to have cultural sensitivities and break away from cultural biases, to understand and to appreciate cultural diversity, and to have culturally responsive skills. While the meaning of Eling tanpo nyanding is remember will be fellow, remind each other and remember to God. It can be interpreted that Eling tanpo nyanding is an unconditional reciprocity without discriminating people and enabling the counselee to achieve a silence that will grow his potential, this is commonly called expertise of nerimo ing pandum. This is in line with the opinion of Rogers (2002) states the counselor is 
required to accept konseli as it is and free from various analysis of prejudice.

Raden Mas Panji Sosrokartono, as his helper and benefactor, has his life with motto: soegih tanpo bondo, digdoyo tanpo adji, ngaloeroeg tanpo bolo, won tapo ngasoraken (Aksan, 1998). It can be interpreted that Soegih tanpo bondo, is the manifestation of human human being rich though not wealthy, but must feel enough to be able to spirited and grateful for the favors, so always able to give and help others. Digdoyo tanpo adji a person who is powerful, respected and respected by many people, does not have to have a talisman or physical strength but a person who helps many others. Furthermore Ngaloeroeg tanpo bolo, the man who fought (ngeluruk) did not have to deploy troops (bala), but through the inner power that can work with his own hands without asking for help from others. Based on these interpretations commonly referred to as a person who has a Sincere Manifest Skill. According Sanyata, (2006) states that the principle of value built in the counselor is the sincerity in providing assistance to the counselee (Sanyata, 2006). Furthermore Canvanagh (1982) states the personal quality of the counselor is a sincere action in the ministry and has the power to nurture.

Based on the above data exposure can be concluded the teachings of the noble Raden Mas Panji Sosrokartono gave birth to the understanding of the therapeutic relationship based on the teachings of the noble Raden Mas Panji Sosrokartono to form a counselor figure mulang kaweruh (guides), mentors who understand the state of his pupil without showing greatness as a Rescuers but inward make counselee feel comfortable if met with counselor figure. Basic skills of the counselor based on the teachings of the noble Raden Mas Panji Sosrokartono as an effort to form therapeutic relationship as follows: (1) to as the agility of creativity, feeling and intention; (2) expertise of empathy; (3) expertise of help; (4) virtuous leadership; (5) the cultural consciousness, and (6) expertise of nerimo ing pandum.

Identification of some forms of teachings Adiluhung Raden Mas Panji Sosrokartono identified to be a therapeutic techniques quoted from the study of the teachings of the teachings Adiluhung Raden Mas Panji Sosrokartono as follows:

\section{Langgeng Tan Ana Susah Tan Ana Seneng, Antheng Mantheng Sugeng Jeneng}

Langgeng tan ana susah tan ana seneng can be interpreted immortality that is not shrouded by feelings of distress or pleasure (Aksan, 1995). While antheng mantheng sugeng jeneng leads to an inner atmosphere that is always calm (Syuropati, 2015). It can be interpreted as a process of spiritual revolution in the self to achieve a silence by holding an inner conection with God in order to achieve a calm inner atmosphere. This is in line with the opinion of Wubbolding (1988) which states the useful counseling technique of asking useful to the therapist in entering the inner world of the client, to gather information, to provide information, and to help clients take more effective control.

According to Jung (2001) the peak of the evolution of the human soul is a symbol of expressing the collection of wisdom that has been achieved in acts that lead to belief in God. Jung further states that a conscious and collective conscious-minded encounter produces intuitive perceptions to encourage individuals to make perfect decisions. This is in line with the opinion of Raden Mas Panji Sosrokartono (in Aksan, 1995) the embodiment of ingsun in the context of Javanese culture is understood as self (self) which consists of the teacher of the self (self) and the self (self) which is the accumulation of The inner human dimension. Kesunyatan Alif is derived through the Lampah Laku Catur Murti which is a mixture and unity of thoughts, feelings, words and deeds, which are united in a silence to receive a whisper of the heart that produces a true truth capable of snorting the negative will or feel.

Based on the text above exposure can be interpreted therapeutic technique of langgeng tan ana susah tan ana seneng, antheng mantheng sugeng jeneng consists of four stages as follows: (1) langgeng tan ana susah tan ana seneng, that is free from the sense of distress and happy, to harmonize the will with the mind (nglaras batos saha raos) so as to create tranquility (antheng) to meditate (mantheng) so as to achieve silence; (2) jeneng, jumeneng or throne, after the achievement of antheng-mantheng, do the consciousness to rise to become true self with the mighty and full of courage like ngelurug tanpo bolo; (3) give worldly feelings to get inner calm; (4) Closer to God to get the whisper of heart that brought man to achieve a true truth.

\section{Ngupasi Padhang Ing Peteng}

The meaning of ngupasi padhang ing peteng is seeking light in the dark (Suxmantojo, 1971). According to Raden Mas Panji Sosrokartono hidden dimension of peteng is a form of misery and padhang is a form of pleasure. The noble teachings of Raden Mas Panji Sosrokartono teaches about the existence of dualism in this world that is padhang-peteng, seneng ing sengsara, healthy-sick and so on. According to Raden Mas Panji Sosrokartono (in Aksan, 1995) it is expected that humans are able to understand the meaning of life to be happy and hard to be accepted with the chest, in this case Raden Mas Panji Sosrokartono called it with the term tunggaling sewu yuta. Can be interpreted ngupasi padhang ing peteng; Seneng ing sengsara; Tunggaling sewu yuta is a wise expression that we should ponder, because the string of sentences that seem simple but contains a noble doctrine that contains meaning wherever you find darkness, then light wherever you find misery then give pleasure. This is commonly referred to as metaphorical techniques, according to Wubbolding \& Brickell, (1998) suggests techniques that use client languages can help in communicating understanding to clients through the use of language. Further Gladding (2012) states that the therapist is expected to create an atmosphere of acceptance and warmth 
assisting the client's focus on mind control being displayed.

Based on the above data exposure can be interpreted therapeutic techniques from ngupasi padhang ing peteng; seneng ing sengsara; consists of two stages as follows: (1) interpretation of padhang ing peteng refers to the effort to change the negative things into positive, this is in line with the aim of cognitive restructuring techniques that focus on identifying and converting negative thoughts into new, more rational and adaptive beliefs that will affect more rational and adaptive behavior (Cormier \& Hackney, 2011); and (2) the interpretation of seneng ing sengsara is to take the hidden wisdom from the misery.According to Raden Mas Panji Sosrokartono (in Aksan 1995) the wisdom of misery is as follows: (a) Give meaningful lessons, (b) lessons the best of our lives deriving from misery, (c) tribulation is a wise teacher, (d) tribulations of endurance, strength and courage, and (e) tribulation is the best tester for human personality.

\section{CONCLUSION}

The essence that we can extract from the description of the exposure in the future is the effort of saintifikasi formulation of the teachings of the noble Raden Mas Panji Sosrokartono on linuwih counseling which is a breakthrough to cultivate the counseling approach of the Indonesian cultural thinking. Qualitative method with the type of hermeneuitika study in this research is used in collecting data on the whole collection of texts of the teachings of the noble Raden Mas Panji Sosrokartono. The entire data is collected by considering the relevance of the findings of the texts of Dhuh Sosrokartono's powerful teachings with the counseling framework.

Description and explanation of the main elements Linuwih counseling comes with an explanation of the main elements of: (1) basic philosophy; (2) human personality structure; (3) counseling purpose; (4) counseling relationship; and (5) techniques counseling. Linuwih counseling comes from an interdisciplinary science base that does not rely on psychology. The idea in this study is a preliminary study of the teachings of the noble Raden Mas Panji Sosrokartono which certainly requires a lot of criticism from other scientists who deepen the teachings of the noble Raden Mas Panji Sosrokartono, as well as scientists in the field of guidance and counseling.

\section{REFERENCES}

[1] ABKIN. 2007. Rambu-Rambu Penyelenggaraan Bimbingan dan Konseling dalam Jalur Pendidikan Formal. Bandung: ABKIN.

[2] Aksan. 1995. Gema Suara: Drs RMP. Sosorkartono. Surabaya: Yayasan Djojo Bojo.

[3] Aksan. 1995. Ilmu dan Laku Drs R.M.P Sosrokartono. Surabaya: PT Citra Jaya Murti

[4] Ali, R. M. 1966. Ilmu Kantong Bolong, Ilmu Kantong Kosong, Ilmu Sunyi Drs. RMP Sosrokartono, Suatu Tanggapan. Jakarta: Panitia Penyusunan Buku Riwayat Drs. RMP Sosrokartono.
[5] Andi Mappiare, A. T. 2014. Meramu Model Konseling Berbasis Budaya Nusantara: KIPAS. Research Report: State University of Malang.

[6] Bitter, J. R. 2013. Theory and Practice of Family Therapy and Counseling. New York: Cengage Learning.

[7] Bozarth, J. D. 1997. Empathy from the Framework of Client-Centered Theory and the Rogerian Hypothesis. New York: Batam Books.

[8] Cavanagh, P. R., \& Williams, K. R. 1982. The Effect of Stride Length Variation on Oxygen Uptake During Distance Running. Medicine and science in sports and exercise, 14(1), 30-35.

[9] Collins, S., \& Arthur, N. 2010. Culture-Infused Counselling: A Fresh Look at a Classic Framework of Multicultural Counselling Competencies. Counselling Psychology Quarterly, 23(2), 203-216.

[10] Corey, G. 1995. Theory and Practice of Group Counseling. New York: Brooks/Cole.

[11] Corey, G. 2005. Theory and Practice of Counseling and Psychotherapy. New York: Thomson Learning, Brooks/Cole.

[12] Corey, G. 2012. Case Approach to Counseling and Psychotherapy. New York: Nelson Education.

[13] Corey, G. 2015. Theory and Practice of Counseling and Psychotherapy. New York: Nelson Education.

[14] Corey, M. S., Corey, G., \& Corey, C. 2013. Groups: Process and Practice. New York: Cengage Learning.

[15] Cormier, S., \& Hackney, H. L. 2011. Counseling Strategies and Interventions. New York: Pearson.

[16] Dewantara, H. 1967. Karja Ki Hadjar Dewantara. Yogyakarta: Madjelis Luhur Persatuan Taman-Siswa.

[17] Endraswara, S. 2013. Мemayu Hayuning Bawana: Laku menuju Keselamatan dan Kebahagiaan Hidup Orang Jawa. Yogyakarta: Narasi.

[18] Gibson \& Mitchel. 2011. Introduction to Counseling and Guidance. Upper Saddle River, NJ: Pearson Prentice Hall.

[19] Gladding, S. T. 2012. Counseling: A comprehensive profession. New York: Pearson.

[20] Goodwin, R., \& Giles, S. 2003. Social Support Provision and Cultural Values in Indonesia and Britain. Journal of Cross-Cultural Psychology, 34(2), 240-245.

[21] Habsy, B. A. 2017. Filosofi Ilmu Bimbingan DAN Konseling Indonesia. Jurnal Pendidikan (Teori dan Praktik), 2(1).

[22] Habsy, B. A. 2017. Semar Puppet Counseling Model. COUNS-EDU: The International Journal of Counseling and Education.

[23] Habsy, B. A. 2017. Model Konseling Kelompok Cognitive Behavior untuk Penanganan Self-esteem Siswa SMK. Jurnal Bimbingan dan Konseling Terapan, 1(2), 86-102.

[24] Hanurawan, F. 2012. Filsafat Ilmu Psikologi. Malang: BKP Universitas Negeri Malang.

[25] Jones-Smith, E. 2011. Theories of Counseling and Psychotherapy: An Integrative Approach. New York: Sage Publications.

[26] Jung, C. G. 1935. Modern Man in Search of a Soul. The Journal of Nervous and Mental Disease, 81(6), 715.

[27] Jung, C. G. 2001. Modern Man in Search of a Soul. New York: Psychology Press.

[28] Kim, H. S., Sherman, D. K., \& Taylor, S. E. 2008. Culture and Social Support. American Psychologist, 63(6), 518.

[29] Leach, M. M., \& Aten, J. D. 2010. Culture and-the Therapeutic Process. New York: Psychology Press. 
[30] Mappiare, A. 2010. Pengantar Konseling dan Psikoterapi. Malang: State University of Malang.

[31] Mappiare, A. 2013. Martabat Konselor Indonesia dalam Falsafah dan Kinerja Model KIPAS: Konseling Intensif Progresif Adaptif Struktur. Proceeding International Seminar ABKIN, Denpasar Bali, 14-16 November.

[32] O'Sullivan, T. L., Fortier, M. S., Hogg, W., Blanchard, C., Reid, R. D., Sigal, R. J., \& Beaulac, J. 2007. The Physical Activity Counselling (PAC) Randomized Controlled Trial: Rationale, Methods, and Interventions. Applied Physiology, Nutrition, and Metabolism, 32(6), 1170-1185.

[33] Paroesno. 1954. Karena Panggilan Ibu Sejati: Riwayat Hidup dari Drs. R.M.P Sosrokartono. Djakarta: Djembatan.

[34] Partosatmoko, K. 1972. Shantih Tuntunan Ethikopsikologik Drs. R.M.P. Sosrokartono. Surabaya: PT Citra Jaya Murti.

[35] Pedersen, P. B. 1991. Introduction to the Special Issue on Multiculturalism as a Fourth Force in Counseling. Journal of Counseling \& Development, 70(1), 4-4.

[36] Prayitno, H. 2013. Sosrokartono De Javasche Prins (Putra Indonesia yang Besar). Semarang: Pustaka Jungpara.

[37] Ridjal, T. 2000. Wong Njaba, Wong Njero, dan Wong Mambu-Mambu di Sumberarum Jombang: Studi tentang Proses Perubahan dari Monokulturalitas ke Interkulturalitas. Dissertation. Surabaya: Airlangga University.

[38] Rogers, B. (2002. Teacher Leadership and Behaviour Management. New York: SAGE.

[39] Sanyata, S. 2006. Perspektif Nilai dalam Konseling: Membangun Interaksi Efektif Antara Konselor-Klien. Paradigma, 1(02).

[40] Suseno, F. M. 2001. Etika Jawa. Jakarta: Gramedia.

[41] Suxmantojo. 1971. Kumpalan Serat-serat Drs. R.M.P Sosrokartono. Jakarta: Panitia Buku Riwayat Drs. R.M.P Sosrokartono.

[42] Syuropati, M. A. 2014. Ajaran-Ajaran Adiluhung Raden Mas Panji Sosorokartono. Semarang: Pustaka Jungpara.

[43] Watson, V. 2011. Training for Multicultural Therapy: The Challenge and the Experience. New York: SAGE.

[44] Wubbolding, R. E. 1988. Using reality therapy. New York: Perennial Library.

[45] Wubbolding, R. E., Al-Rashidi, B., Brickell, J., Kakitani, M., Kim, R. I., Lennon, B., \& Tham, E. 1998. Multicultural Awareness: Implications for Reality Therapy and Choice Theory. International Journal of Reality Therapy, 17(2), 4-6.

[46] Zaretsky, T. 1995. He Birth of Identity Politiccs in the 1960 - Psychoanalysisi and the Public/Private Division. In Fietherston, M., (Ed)., Global Modernities. London: SAGE Publications.

[47] Zenner, H. P., Delb, W., Kröner-Herwig, B., Jäger, B., Peroz, I., Hesse, G., \& Biesinger, E. 2016. A Multidisciplinary Systematic Review of the Treatment for Chronic Idiopathic Tinnitus. European Archives of Oto-Rhino-Laryngology, 1-13. 